\title{
PEACEFUL SETTLEMENT OF DISPUTES IN OCEAN CONFLICTS: DOES UNCLOS III POINT THE WAY?
}

\author{
LOUIS B. SOHN*
}

\section{INTRODUCTION}

One of the important accomplishments of the Third United Nations Law of the Sea Conference is the development of a veritable code for the settlement of the disputes which may arise with respect to the interpretation and application of the Law of the Sea Convention. ${ }^{1}$ It was recognized early in the negotiations that if the parties to the Convention had retained the right of unilateral interpretation, then the complex text drafted by the Conference would have lacked stability, certainty, and predictability. ${ }^{2}$ It is one of the prerogatives of sovereign equality that in the absence of an agreement on impartial third-party adjudication, the view of one state with respect to the interpretation of the Convention cannot prevail over the views of other member states. ${ }^{3}$ Each party can claim forever that its view alone is correct, but another party can make the same claim, resulting in an impasse.

The only effective remedy in such a situation is to provide in advance in the Convention itself for an effective method of settling future interpretation disputes. In the past, several groups of states have usually refused to accept such a solution, and at the 1958 Law of the Sea Conference, agreement was reached only on an optional protocol which very few states ratified. ${ }^{4}$ The general importance of the

Copyright (C) 1983 by Law and Contemporary Problems

* Woodruff Professor of International Law, University of Georgia School of Law.

1. See Convention on the Law of the Sea opened for signature Dec. 10, 1982, U.N. Doc. A/CONF.62/122 (1982), arts. 279-99, 186-91 [hereinafter cited as Convention], reprinted in 21 I.L.M. 1261 (1982). Concerning the evolution of the dispute settlement provisions in the Law of the Sea Convention, see Adede, Prolegomena to the Disputes Settlement Part of the Law of the Sea Convention, 10 N.Y.U. J. INT'L L. \& ECON. 253 (1977); Adede, Streamlining the System for Setllement of Dispules under the Law of the Sea Convention, 1 PACE L. REV. 15 (1980); Caflisch, Le réglement judiciaire et arbitral des differends dans le nouveau droit international de la mer, FESTSCHRIFT FÜR R UDOLF BINDSCHEDLER 351 (1980); Rosenne, The Settlement of Disputes in the New Law of the Sea, 11-12 REVUe IRANIENNE DES RELATIONS INTERNATIONALEs 401 (1978); Sohn, Seltlement of Dispules Arising out of the Law of the Sea Convention, 12 SAN Dieco L. REv. 495 (1975); Sohn, Toward a Tribunal for the Oceans, 5-6 REVUE IRANIENNE DES RELATIONS INTERNATIONALES 247 (1975-76).

2. In his statement to the U.N. Committee on the Peaceful Uses of the Seabed and the Ocean Floor on August 10, 1972, John R. Stevenson stated that effective assurance was needed that the international standards to be agreed upon will be observed. In his words, "Adequate assurance can only be provided by an impartial procedure for the settlement of disputes. These disputes, in the view of my delegation, must be settled ultimately by the decision of a third party. For us, then, the principle of compulsory dispute settlement is essential." 67 DeP'T ST. BuLl. 382, 384 (1972).

3. Cf. Jesse Lewis (The David J. Adams) Claim (U.S. v. Great Britain), 6 R. Int'l Arb. Awards 85, 89 (1921); McNair, The LaW of Treatit.s 345-50 (1961).

4. Optional Protocol of Signature concerning the Compulsory Settlement of Disputes, opened for signa- 
latest Law of the Sea Convention and the need to protect the agreed package of compromises against destruction through unchallengable unilateral interpretations have led the reluctant states to abandon their opposition to binding provisions for the settlement of disputes. ${ }^{5}$

\section{II}

\section{The General Framework for Dispute Settlement}

The resulting system for the settlement of law of the sea disputes is at the same time simple and complex. Its simplicity is due to the fact that the Convention accepts as its guiding principle that in general the will of the parties to a dispute shall prevail and that the parties may by agreement select any dispute settlement method they wish. ${ }^{6}$ The more complex provisions apply only if the parties do not agree upon a dispute settlement method. ${ }^{7}$

Even after a dispute has arisen, and even if one of the procedures provided for in the Convention has been started, the parties can agree "at any time" to adopt a special method for settling their dispute. ${ }^{8}$ Similarly, if the parties to a dispute have previously agreed, in a bilateral, regional, or general international agreement, to set tle disputes (including those relating to the interpretation of international agreements between them) by a procedure entailing a binding decision, this procedure supersedes the procedures provided for in the Law of the Sea Convention. ${ }^{9}$

For example, if the two parties to the dispute have agreed unconditionally to accept the jurisdiction of the International Court of Justice, either of them can refer the dispute to that forum. Some African countries have expressed preference for submitting the disputes relating to the interpretation or application of the Law of the Sea Convention to the Commission of Mediation, Conciliation, and Arbitration of the Organization of African Unity; ${ }^{10}$ if they agree to accept as binding a decision of that Commission, such an agreement will prevail over the Law of the Sea Convention provisions for settlement of disputes. If, however, the procedure chosen by the parties does not lead to a binding decision, the jurisdiction of the institutions established by the Law of the Sea Convention revives, and a party to the dispute can resort to these institutions. ${ }^{11}$ Similarly, the provisions of the Convention come into play whenever the parties have not been able to settle the dispute by negotiations or conciliation and have not succeeded in agreeing on another method of settlement. ${ }^{12}$

ture Apr. 29, 1958, 450 U.N.T.S. 169. It was ratified by 37 states, but the United States did not become a party to it.

5. In particular, the Soviet Union and its allies, as well as the African states, have for the first time agreed to this method of settlement for an important general convention.

6. See Convention, supra note 1 , art. 280.

7. Id. art $281(1)$.

8. Id. art 280.

9. Id. art 282.

10. For the text of the Protocol of July 1964 establishing that Commission, see 1 BasiC DoCumENTS () A Arican Regional. Organizations 69 (L. Sohn ed. 1971)

11. Convention, supra note 1, art. 286.

12. Id. 
Flexibility does not stop at this stage. Unlike most other international instruments, the Law of the Sea Convention does not provide for a unitary system of dispute settlement. Various groups of states have expressed preferences for different methods of settling Convention disputes. Some states have argued for conferring the jurisdiction to interpret the Convention on the International Court of Justice; ${ }^{13}$ others have expressed preferences for arbitration; ${ }^{14}$ while some have supported special technical commissions; ${ }^{15}$ a large group of states has opted for a permanent International Tribunal for the Law of the Sea. ${ }^{16}$ After many other solutions were rejected, it was agreed that a state can choose any one of these four methods, but if the two states concerned have chosen different methods, the dispute may be submitted "only to arbitration." 17 All states agreed that if they cannot have the tribunal of their choice they would be willing to go to arbitration. To ensure that this solution will work, an annex to the Convention provides an effective method for selecting the arbitral tribunal. ${ }^{18}$

\section{III}

\section{Settlement of Specific Categories of Disputes}

Three categories of cases are subject, however, to different procedures: (a) Article 297 governs disputes relating to the exercise by a coastal state of its sovereign rights or jurisdiction in the Exclusive Economic Zone (EEZ); (b) Article 298 governs disputes relating to sea boundary delimitations, to military or law enforcement activities, or to disputes submitted to the Security Council of the United Nations; and (c) Articles 186-91 govern disputes relating to seabed mining. The simplicity of the other provisions of the Convention is matched by the complexity of these three exceptions.

\section{A. Exclusive Economic Zone.}

Disputes relating to the Exclusive Economic Zone are in turn subdivided into three categories: ${ }^{19}$

(i) Disputes relating to violations by either the coastal state or any other state of the provisions of the Convention in regard to freedoms and rights of navigation, overflight, the laying of submarine cables and pipelines, or other internationally lawful uses of the sea, as well as those relating to violations by the coastal state of international rules and standards for the protection and preservation of the marine environment, are subject to the general system for the settlement of disputes. ${ }^{20}$

(ii) Disputes relating to marine scientific research are further subdivided into three categories: some are subject to the general system of dispute settlement;

13. E.g., Japan and the Netherlands.

14. E.g., France, the United Kingdom, and the United States.

15. E.g., the Soviet Union and other Eastern European states.

16. Most African states and several Latin American states have supported this idea.

17. Convention, supra note 1 , art. $287(1),(5)$.

18. Id. annex VII.

19. Id. art. 297.

20. Id. art. $297(1)$ 
some are completely excluded from that system due to their discretionary character; and some are subject to compulsory conciliation (a procedure which can be resorted to by either party to the dispute but which leads only to a report, not to a binding decision). ${ }^{21}$

(iii) Disputes relating to fisheries are similarly divided into three categories, ${ }^{22}$ paralleling those under (ii).

B. Sea Boundary Delimitations, Military or Law Enforcement Activities, and Disputes Before the U.N. Security Council

While the exceptions relating to the EEZ are automatic, ${ }^{23}$ the exceptions enumerated in Article 298 are optional. In becoming party to the Convention, a state may make a declaration that it does not accept the dispute settlement procedures of the Convention with respect to one or more of the following three categories of disputes: 24

(i) Disputes concerning sea boundary delimitations or involving historic bays or titles are subdivided into four categories. Those which arose before the entry into force of the Convention are totally exempt from dispute settlement under the Convention; those which shall arise after the entry into force of the Convention will be subject to compulsory conciliation; mixed disputes which involve the concurrent consideration of sea boundaries and of any unsettled dispute concerning sovereignty or other rights over continental or insular land territory are totally excluded from dispute settlement under the Convention; and sea boundary disputes which have been finally settled by an arrangement between the parties or which are to be settled in accordance with an agreement between them are also totally excluded from dispute settlement under the Convention. ${ }^{25}$

(ii) Disputes concerning military activities are completely exempt from dispute settlement under the Convention; disputes concerning law enforcement activities are exempt if they are connected with disputes involving fishing or marine scientific research ${ }^{26}$ since these latter disputes are themselves completely exempt from dispute settlement under the Convention. ${ }^{27}$

(iii) Disputes which are being dealt with by the U.N. Security Council are totally exempt from dispute settlement under the Convention as long as they are before the Council. ${ }^{28}$

\section{Seabed Mining}

In earlier drafts of the Convention, disputes relating to seabed mining were

\footnotetext{
21. Id. art. 297(2).

22. Id. art. 297(3).

23. Id. art. 297.

24. Id. art. $298(1)$

25. Id. art. $298(1)(\mathrm{a})$

26. Id. art. 298(1)(b).

27. Id. art. 297.

28. Id. art. 298(1)(c).
} 
originally subject to a special Seabed Tribunal. ${ }^{29}$ However, once agreement was reached on an International Tribunal for the Law of the Sea, composed of twentyone members elected at a meeting of all the parties to the Convention, ${ }^{30}$ many states became reluctant to maintain two separate tribunals. ${ }^{31}$ Further negotiations resulted in the unification of the two tribunals and the establishment within the International Tribunal for the Law of the Sea of a separate Seabed Disputes Chamber, composed of eleven members selected by a majority of the Tribunal from among its members. ${ }^{32}$ The jurisdiction of the Chamber embraces most disputes relating to seabed mining, except that some disputes are subject to other procedures and some disputes are completely exempt from any dispute settlement procedure. ${ }^{33}$

While the general dispute settlement system applies only to disputes between states, the seabed dispute settlement system applies in addition to disputes between states and the International Seabed Authority and to contract disputes involving states, the Authority, the Enterprise (the mining arm of the Authority), state enterprises, and natural and juridical persons. ${ }^{34}$ The Seabed Disputes Chamber has exclusive jurisdiction over most of these disputes, but some disputes between states may be submitted instead to a smaller chamber, chosen either from the Tribunal as a whole or from the Seabed Disputes Chamber. ${ }^{35}$

In view of the technical character of many contract disputes, it was agreed that at the request of any party to the dispute, such disputes shall be submitted to binding commercial arbitration, ${ }^{36}$ and that such arbitration shall be conducted in accordance with the generally accepted UNCITRAL Arbitration Rules, ${ }^{37}$ prepared by the U.N. Commission on International Trade Law and approved by the U.N. General Assembly in 1976. Similarly, commercial arbitration may be resorted to in disputes relating to transfer of seabed mining technology and to financial terms of mining contracts. ${ }^{38}$

Some states strongly opposed the idea that should a dispute be a mixed one, involving the interpretation of both a contract and the Convention, the interpretation of the Convention would be referred to a commercial arbitral tribunal. ${ }^{39}$ It was agreed, therefore, that in such a case the arbitral tribunal would refer the question of Convention interpretation to the Seabed Disputes Chamber for a ruling and that the tribunal's award should be rendered in accordance with such

29. See, e.g., Informal Single Negotiating Text, U.N. Doc. A/CONF.62/WP.8/Part I, arts. 32-34 (1975); 4 UNCLOS III, at 137, 144 (1975).

30. Convention, supra note 1 , annex VI, arts. 1, 4

31. See Adede, Law of the Sea-The Integration of the System of Settlement of Dispules under the Draft Convention as a Whole, 72 AM. J. INT'L L. 84, 84.95 (1978). See also Sohn, Settlement of International Disputes relating to Deep Sea-bed Mining, Festschrift für Rudolf Bindschedler 443, 445 (1980).

32. Convention, supra note 1 , annex VI, art. 35.

33. See id. arts. 186-91.

34. Id. art. 187.

35. Id. art. $188(1)$.

36. Id. art. 188(2).

37. Report of the U.N. Commission on International Trade Law, 31 U.N. GAOR Supp. (No. 17) at 35, U.N. Doc. A/31/17 (1976); 7 UNCITRAL Y.B. 22 (1976).

38. Convention, supra note 1 , annex III, arts. 5(5), (13), (15).

39. E.g., the Soviet Union, India, and several Latin American states. 
ruling. ${ }^{40}$

Another difficulty arose concerning the power of the Seabed Disputes Chamber to declare that certain acts of the Authority were invalid. It was made clear that the Chamber would have no jurisdiction with respect to the exercise by the Authority of its discretionary powers, and that in no case should it substitute its discretion for that of the Authority. ${ }^{41}$ But if the Authority should act outside the limits of its discretion, lack competence, or misuse its powers, the Chamber would have jurisdiction to deal with such issues since such acts would not be considered discretionary. While the Chamber would have no power to declare any rules, regulations, or procedures invalid, it would be permitted to grant reparation or provide other remedies to the party which had suffered damage as a result of another party's failure to comply with its obligations under the Convention or a contract. ${ }^{42}$

Despite the complexity of these provisions, in the last sessions of the Conference there was no disposition to challenge them, and it can be assumed that with respect to them a consensus has been reached. Of course, most of the substantive provisions of the Convention might come to reflect customary international law, so that nonparties to the Convention might be able to invoke them; yet the dispute settlement provisions will be available only to parties to the Convention. ${ }^{43}$ Should a dispute arise between a state party to the Convention and a state not a party thereto, such a dispute would have to be resolved in accordance with procedures available to the parties to the dispute outside the Convention. At present, such procedures are seldom available. As the United States has found out in its disputes with Canada and Latin American states in the last decades, without a satisfactory dispute settlement system even a powerful nation cannot adequately protect its citizens and ships against harmful acts of foreign governments who are not willing to submit to impartial adjudication. ${ }^{44}$ On the other hand, for disputes between parties to the Convention the system of dispute settlement provided by the Convention, though it appears extremely flexible and provides several options, in the great majority of cases can lead to a binding decision likely to be accepted and complied with by the parties to the dispute. This is the way to the rule of law and to ensuring that the peace of the world will not be jeopardized by a dangerous escalation of law of the sea controversies.

40. Convention, supra note 1, art. 188(2).

41. Id. art. 189

42. Id. arts. $187($ b), 189.

43. The provisions of part XV of the Convention relating to settlement of disputes apply only to "States Parties [to the Convention]." See id. art. 279. As the Permanent Court of International Justice has stated in the Eastern Carelia Case, "[i]t is well established in international law that no State can, without its consent, be compelled to submit its disputes with other States either to mediation or arbitration, or to any other kind of pacific settlement." P.C.I.J., Series B, No. 5, at 27 (1923).

44. See 4 M. Whiteman, Digest OF International Law 1101-03 (1965) (United States-Latin American fishing disputes); Beasley and Bourne, Canadian Practice in International Law during 1970 as Reflecled Mainly in Public Correspondence and Statements of the Department of External Affairs, 9 CAN. Y.B. INT'L L. 276, 28794 (1971) (United States-Canadian dispute about the Arctic pollution control zone). 